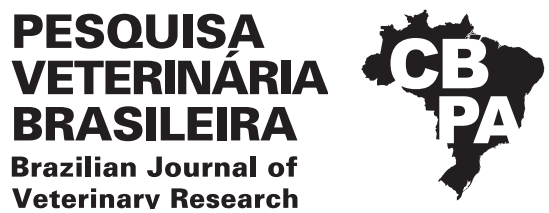

Pesq. Vet. Bras. 41:e06910, 2021

DOI: $10.1590 / 1678-5150-P V B-6910$

Original Article

Veterinarv Research

ISSN 0100-736X (Print)

ISSN 1678-5150 (Online)

\title{
Immunogenicity of Streptococcus equi subsp. equi recombinant SeM protein and bacterin in mice ${ }^{1}$
}

\begin{abstract}
Matheus C. Rosa ${ }^{2}$, Neida Lucia Conrad ${ }^{2}$, Carina M. Moraes ${ }^{3}$ and Fábio P.L. Leite ${ }^{2 *}$ (D)
ABSTRACT.- Rosa M.C., Conrad N.L., Moraes C.M. \& Leite F.P.L. 2021. Immunogenicity of Streptococcus equi subsp. equi recombinant SeM protein and bacterin in mice. Pesquisa Veterinária Brasileira 41:e06910, 2021. Biotecnologia, Centro de Desenvolvimento Tecnológico, Universidade Federal de Pelotas, Campus Capão do Leão, Pelotas, RS 96010-900, Brazil. E-mail: fleivasleite@gmail.com

The infection caused by Streptococcus equi, known as strangles, affects the respiratory system of horses, causing high morbidity and rapid spread among the herd. Bacterin vaccines, composed of inactivated whole cells of $S$. equi, have variable efficacy and duration. Infected animals produce specific antibodies against SeM, the immunodominant antigen of $S$. equi. This makes it a promising target for vaccine development. In this context, the objective of this work was to evaluate a vaccine combining S. equi bacterin and recombinant SeM protein. Mice were vaccinated with bacterin (S. equi $\left.\sim 1.2 \times 10^{8} \mathrm{CFU} / \mathrm{ml}\right)$; rSeM protein $(20 \mu \mathrm{g})$; bacterinrSeM combination; or PBS (Control Group) and challenged with a suspension of S. equi, containing $10 \times \mathrm{LD}_{50}$. All vaccinated mice survived the challenge and produced anti-rSeM and anti-S. equi antibodies, which were assessed by indirect ELISA. The Control Group reached endpoint criteria $96 \mathrm{~h}$ after infection. These results demonstrate that a vaccine combining the $S$. equi bacterin with $\mathrm{rSeM}$ protein protects mice against strangles. This combination vaccine could potentially protect horses and overcome the limitations of currently available strangle vaccines.
\end{abstract}

INDEX TERMS: Immunogenicity, Streptococcus equi, mice, strangles, vaccine, SeM protein, bacterin, antibodies.

\begin{abstract}
RESUMO.- [Imunogenicidade da proteína recombinante SeM de Streptococcus equi subsp. equi e da bacterina em camundongos.] A infecção causada por Streptococcus equi, denominada adenite, atinge o sistema respiratório de equinos, causando alta morbidade e rápida disseminação entre o rebanho. Vacinas bacterinas, compostas de células inteiras inativadas de $S$. equi apresentam eficácia e duração variáveis. Animais infectados apresentam anticorpos específicos à proteína SeM, antígeno imunodominante de $S$. equi, o que a torna um alvo promissor para o desenvolvimento de vacinas. Neste contexto, o objetivo deste trabalho foi avaliar uma vacina baseada na administração simultânea da bacterina e da proteína SeM recombinante. Camundongos foram vacinados com a bacterina (S. equi $\sim 1.2 \times 10^{8} \mathrm{CFU} / \mathrm{ml}$ ); a proteína $\mathrm{rSeM}$
\end{abstract}

\footnotetext{
${ }^{1}$ Received on July $15,2021$.

Accepted for publication on July 29, 2021.

${ }^{2}$ Biotecnologia, Centro de Desenvolvimento Tecnológico, Universidade Federal de Pelotas (UFPel), Campus Capão do Leão, Pelotas, RS 96010-900, Brazil. *Corresponding author: fleivasleite@gmail.com, fabio_leite@ufpel.edu.br

${ }^{3}$ Universidade Federal do Pará (UFPA), Campus Castanhal, Av. dos Universitários s/n, Jaderlândia, Castanhal, PA 68746-630, Brazil.
}

$(20 \mu \mathrm{g})$; a bacterina e rSeM simultaneamente; ou PBS (Grupo Controle) e, posteriormente, foram desafiados com uma suspensão de $S$. equi contendo $10 \times \mathrm{LD}_{50}$ Todos os animais vacinados apresentaram anticorpos anti-rSeM e contra $S$. equi, avaliados através de ELISA indireto, e mantiveram-se e sobreviveram ao desafio letal. 0 Grupo Controle atingiu critérios de endpoint 96 h após a infecção. Estes resultados demonstram que uma vacina constituída de células inteiras de $S$. equi com rSeM protege camundongos contra adenite, sugerindo a capacidade de proteção a equinos e, possivelmente, superando as limitações das vacinas contra adenite atualmente disponíveis.

TERMOS DE INDEXAÇÃO: Imunogenicidade, Streptococcus equi, camundongos, garrotilho, vacina, proteína SeM, bacterina, anticorpos.

\section{INTRODUCTION}

Equines represent an important economic sector worldwide, playing a role in tourism, transport, sports and leisure. The breeding of high-quality animals raises the growth prospect of the sector. However, the occurrence of infectious diseases 
can hinder this trend. Since the XIX century, strangles has been one of the most important diseases in the industry, causing huge economic losses worldwide (Harrington et al. 2002).

Strangles is caused by Streptococcus equi, a Gram positive B-hemolytic bacteria belonging to the Lancefield group C (Timoney et al.1997). Two subspecies of $S$. equi are the main causers: S. equi subsp. equi and S. equi subsp. zooepidemicus. $S$. equi subsp. equi is the most notorious agent associated with the greatest economic losses to equine husbandry since it causes pulmonary infections and reduces performance (Waller et al. 2011). S. equi subsp. zooepidemicus is associated with a wide variety of infections in many animal species including horses, cows, swine, sheep, and dogs (Acke et al. 2015). This disease affects the upper respiratory tract of young horses and is characterized by swelling of the throat lymph nodes, purulent nasal discharge, cough and fever (Wyngaarden \& Smith 1985).

Streptococcus equi synthesizes several virulence factors, among these factors the M protein (SeM) stands out for its antiphagocytic and adherence capacity, having an important role in pathogenesis (Timoney et al. 1997, Flock et al. 2004). The humoral immune response to $S$. equi is characterized by the presence of IgG and IgA antibodies against the SeM protein. This protein is detected in both serum and nasal secretions making it a promising antigen for diagnostics and vaccine development (Harrington et al. 2002, Lindahl et al. 2011).

Bacterin vaccines against strangles have been used for infection control and prevention since the 50s, despite their limited and variable efficacy (Timoney \& Eggers 1985). In Brazil, for example, effectiveness is around 50\% (Libardoni et al. 2016). However, animals develop a protective and lasting immunity in response to natural infections. This demonstrates potential for the development of an efficient strangles vaccine (Hamlen et al. 1994).

Despite its limitations, the bacterin provides moderate protection against strangles. Furthermore, the protective response triggered by natural infection contains anti-SeM antibodies. Considering this we aimed to evaluate a vaccine which combined the bacterin and the recombinant protein rSeM.

\section{MATERIALS AND METHODS}

Antigens. Two different antigens were produced: the bacterin and the SeM recombinant protein. Each antigen was tested separately and together, and an adjuvant was included in both cases. For bacterin production, a previously characterized isolate of Streptococcus equi subsp. equi was grown in brain heart infusion (BHI, Difco, USA) and shaken at $37^{\circ} \mathrm{C}$ overnight (Moraes et al. 2009). Cultures were centrifuged at $332 \times g$, and pellets were resuspended in sterile saline buffer. To determine the bacterial concentration, cultures were serially diluted and plated on blood agar for colony counting. Suspensions containing $2.5 \times 10^{8} \mathrm{CFU} / \mathrm{ml}$ were inactivated with formaldehyde $(5 \%)$ for $24 \mathrm{~h}$ at $37^{\circ} \mathrm{C}$. Suspensions were tested for safety, sterility and purity. The $S$. equi subsp. equi protein profile was evaluated by SDS-PAGE.

The recombinant protein was produced as previously described (Moraes et al. 2014, Maciel et al. 2017). Briefly, the SeM sequence (access number U73162) was amplified using specific primers (Primer forward: 5'CGGGATCCTCGAGGTTAGTCGTAC3'; primer reverse: 5'GGGGTACCTTAGTTTTCTTTGCGT3') and cloned into the pAE vector (Ramos et al. 2004). The recombinant plasmid pAE/
SeM was transformed into Escherichia coli BL21 Star ${ }^{\mathrm{TM}}$ (DE3) cells. rSeM protein expression and recovery was performed as previously described (Moraes et al. 2014). The recombinant protein was purified by affinity chromatography using both HisTrap ${ }^{\mathrm{TM}} \mathrm{HP} 1 \mathrm{ml}$ columns pre-packed with pre-charged $\mathrm{Ni}$ Sepharose $\mathrm{e}^{\mathrm{TM}}$ and the AKTAprime $\mathrm{T}^{\mathrm{TM}}$ Automated Liquid Chromatography System (GE Healthcare, Little Chalfont, UK). The purified rSeM protein was dialyzed in phosphatebuffered saline (PBS) with decreasing urea concentrations for $72 \mathrm{~h}$ and was then stored at $-20^{\circ} \mathrm{C}$ for further analysis.

The rSeM protein expression was analyzed by $12 \%$ SDS-PAGE in an electrophoresis system following Moraes et al. (2014), then the gel stained with Coomassie Brilliant Blue R250.

Compliance with Ethical Standards. All mice were maintained at the animal care facility from the "Universidade Federal de Pelotas" (UFPel), Brazil, and housed in autoclaved cages (Alesco, Brazil) with no food or water restrictions. All procedures were performed in accordance with guidelines from the Brazilian Committee for animal care and use (COBEA). Experimental protocols were approved by the UFPel Ethics Committee for animal research (project number 1039). All efforts were made to minimize animal suffering.

Mice vaccination. Forty, 6-week-old, Balb/c female mice were randomly allocated into four groups of 10 animals each. Animals were vaccinated with two $100 \mu \mathrm{L}$ doses by intramuscular (IM) injection on the thigh muscle, with 14 days interval between each vaccination as follows: 1 ) Bacterin - S. equi subsp. equi suspension containing $\sim 1.2 \times 10^{8} \mathrm{CFU} / \mathrm{ml}$, inactivated with $37 \%$ formalin $(1: 5.000)$ (Labsynth ${ }^{\circledR}$, São Paulo, Brazil) and adsorbed in $10 \% \mathrm{Al}(\mathrm{OH})_{3}$ adjuvant (Sigma-Aldrich ${ }^{\circledR}$ ); 2) Recombinant antigen - rSeM protein $(20 \mu \mathrm{g})$ adsorbed in $10 \% \mathrm{Al}(\mathrm{OH})_{3}$ adjuvant (Sigma-Aldrich ${ }^{\circledR}$ ); 3) Bacterin/ rSeM combination - an inactivated $S$. equi subsp. Equi suspension containing $\sim 1.2 \times 10^{8} \mathrm{CFU} / \mathrm{ml}$ and $\mathrm{rSeM}$ protein $(20 \mu \mathrm{g})$ adsorbed in $10 \% \mathrm{Al}(\mathrm{OH})_{3}$ adjuvant (Sigma-Aldrich ${ }^{\circledR}$ ); 4) Control Group phosphate buffer saline (PBS) with $10 \% \mathrm{Al}(\mathrm{OH})_{3}$ adjuvant (SigmaAldrich $^{\circledR}$ ). Blood samples were collected on day 0,14 and 28 through submandibular puncture. Serum was separated by centrifugation at $3,000 \times \mathrm{g}$ for $7 \mathrm{~min}$, then stored at $-20^{\circ} \mathrm{C}$ for serological analysis.

ELISA. Indirect ELISAs were carried out using the $S$. equi subsp. equi and rSeM protein. Microtitre plates (Polysorp, Nunc) were coated with heat inactivated $S$. equi $\left(10^{8} \mathrm{UFC} /\right.$ well $)$ or $\mathrm{rSeM}$ protein $(100 \mathrm{ng} /$ well), both diluted in $0.1 \mathrm{M}$ carbonate bicarbonate buffer ( $\mathrm{pH} 9.6$ ) at $4^{\circ} \mathrm{C}$ overnight. The plates were washed $5 \times$ with PBS-T (PBS, $0.05 \%$ Tween 20 ) and incubated with $100 \mu$ of blocking solution (PBS-T, $1 \%$ BSA) for one hour at $37^{\circ} \mathrm{C}$. Mouse serum diluted 1:100 in PBS-T was added and incubated for one hour at $37^{\circ} \mathrm{C}$. After 5 washes with PBS-T, anti-mouse IgG HRP-conjugated antibody (Sigma, USA), diluted 1:5000, was added and incubated for one hour at $37^{\circ} \mathrm{C}$. After 5 washes with PBS-T, $100 \mu$ l of substrate solution (10mg ortho-phenylenodiamine (OPD, Sigma-Aldrich) in $10 \mathrm{ml}$ of $0.1 \mathrm{M}$ phosphate citrate buffer and $10 \mu \mathrm{l}$ of $30 \% \mathrm{H}_{2} \mathrm{O}_{2}$ ) was added to each well. The reaction was developed for 15 minutes and the plate was read in a microplate reader (Mindray MR-96A), at 450nm. The ELISA data was expressed by seroconversion where the absorbance of each sample was divided by that of the animal's serum at day 0 .

Lethal dose $50\left(\mathbf{L D}_{50}\right)$ assay. To evaluate the lethal dose 50 $\left(\mathrm{LD}_{50}\right)$ of the $S$. equi subsp. equi isolate, an assay was performed with three groups of Balb/c mice, containing five animals each. These mice were inoculated in the peritoneum with $10^{1}, 10^{2}$ or $10^{3} \mathrm{CFU}$ of $S$. equi. The animals were monitored three times daily for up to seven days post challenge. Animals that reached endpoint criteria or that survived to day 7 post challenge (PC) were euthanized by $\mathrm{CO}_{2}$ narcosis. 
Vaccine efficacy. All vaccinated groups (Groups 1, 2, 3, and 4) were challenged, by intraperitoneal inoculation, two weeks after the second immunization, with $10 \times$ lethal dose $50\left(\mathrm{LD}_{50}\right)$ to determine the vaccine efficacy against lethal $S$. equi infection.

\section{RESULTS AND DISCUSSION}

Our hypothesis in the present study was that the association of whole cells (bacterin) with a recombinant antigen would give a better vaccine protection, principally considering the amount of rSEM present in the formulation. Thus, the advantages of combining the classic Streptococcus equi bacterin together with $\mathrm{rSeM}$ protein are induction a broader protective vaccinal response against different $S$. equi isolates, also promoting heterologous protection against other S. equi subspecies, such as subsp. zooepidemicus. Also, our working hypothesis was based in study conducted by our group in which was demonstrated that mice vaccinated with different S. equi strains isolated from cases of Strangles had serum cross reactivity that range from $0-100 \%$, however, all sera from the vaccinated mice reacts with the rSEM (Moraes et al. 2009). Also, following similar approach, we had a very promising results, using the inactivated whole virus BoHV5 particle associated with a recombinant gD glycoprotein (Araujo et al. 2018).

To produce the bacterin vaccine, $S$. equi subsp. equi were cultivated, quantified and submitted to electrophoresis (SDS-PAGE) to obtain the protein profile. Among the S. equi proteins, a prominent band, suggesting to the SeM protein, was observed (Fig.1). The SeM recombinant protein, expressed by the Escherichia coli BL21 (DE3) strain, was detected in the insoluble fraction. A $58 \mathrm{kDa}$ protein was detected by SDS-PAGE. This size is equivalent to the expected molecular mass of rSeM (Fig.2). This expression process yielded $\sim 0.9 \mathrm{mg} / \mathrm{L}$ of protein. rSeM was recognized by anti-histidine antibodies and also recognized by $S$. equi vaccinated mice and $\mathrm{rSeM}$ vaccinated mice sera (Fig.3).
Many vaccines employ recently developed technologies, such as toxins, purified fimbriae, subunit proteins and DNA vectors (Boyle et al. 2018, Robinson et al. 2018). However, conventional bacterins still play a major role in preventing diseases (Sturbelle et al. 2013, Zhang 2014). Nevertheless, problems still arise in the production of bacterins, which may fail to contain important protective antigens. Vaccines containing fewer defined antigens may be less reactogenic but also less immunogenic, thus requiring key virulence determinants to boost efficacy (Lima et al. 2004, Strugnell et al. 2011). Difficulties with production, costs, immunogenicity and delivery of purified antigens have motivated research towards improving whole-cell vaccines. Use of a whole-cell pathogen is a straightforward method for developing a vaccine since the complete organisms are likely to contain all of the relevant pathogen-specific antigens for effective immunization. Whole-cell vaccines are comprised of many antigens, as well as molecules important in triggering immune responses (Walker 1992). In addition to specific antigenic components (e. g. adhesin and/or toxins), there are several other microorganism constituents essential for the initiation of the innate and subsequent adaptive immune response. Whole-cell vaccines can be highly effective, especially if the pathogen can be grown quickly in vitro expressing the main protective antigens and being relatively easy to produce (Pace et al. 1998).

The strategy in this study was to develop a strangles vaccine combining antigens with proven efficacy, such as bacterin $(S$. equi whole-cells) and SeM protein, in order to overcome the limitations of using them separately. All vaccinated mice had detectable levels of serum antibodies to $S$. equi whole cells and $\mathrm{rSeM}$ protein 14 days after the first vaccination. This response was detected in serum 14 days after single vaccine dose. When analyzing the response for whole $S$. equi cells, the group vaccinated with the bacterin (Group 1) induced an increase of 0.3 -fold in antibody title after the first dose, and

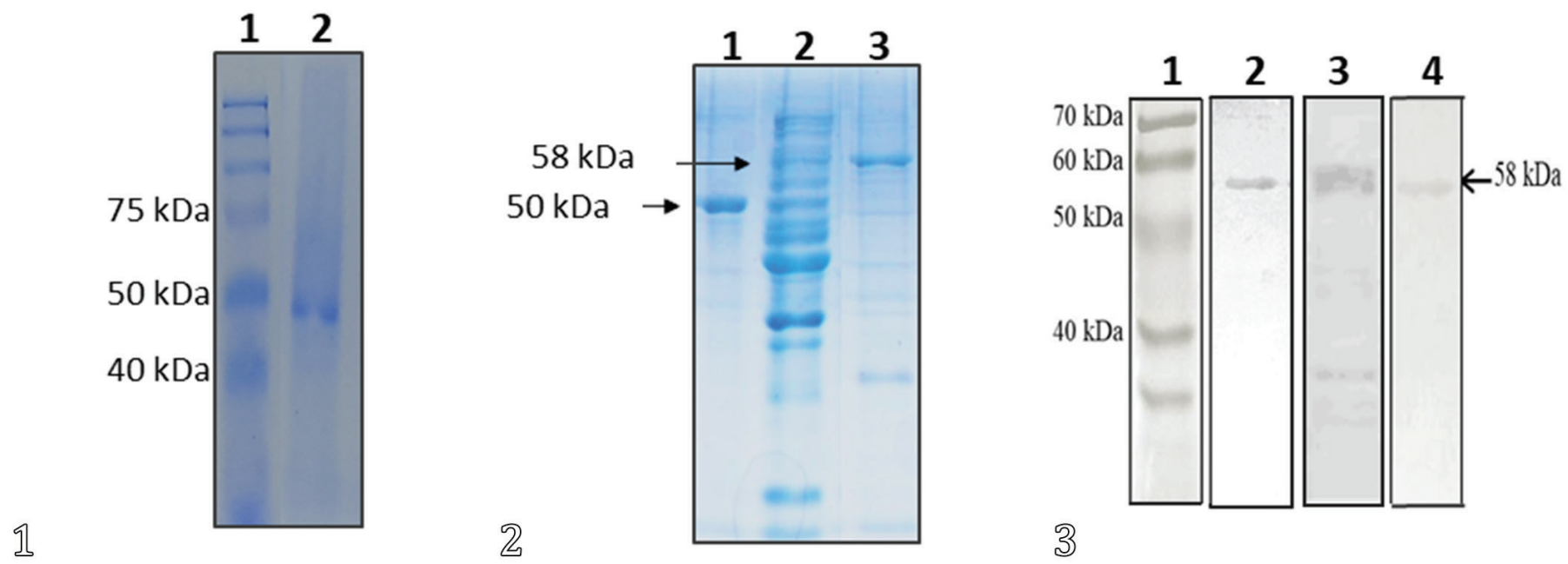

Fig.1-3. Antigens production and characterization. (1) Bacterin protein profile evaluated by $12 \%$ SDS-PAGE. 1 = Protein ladder, 2 = Streptococcus equi subsp. equi $\left(10^{6}\right)$. (2) rSeM expression and purification evaluated by $12 \%$ SDS-PAGE. $1=$ Protein ladder, $2=$ rSeM protein solubilized in urea buffer (not purified), 3 = purified rSeM. (3) Characterization of rSeM protein by Western blot. 1 = Protein ladder, 2 = rSeM probed with anti-histidine monoclonal antibody, $3=\mathrm{rSeM}$ probed with $S$. equi vaccinated mice sera (Group 1), $4=$ rSeM probed with rSeM vaccinated mice sera (Group 2). 
1.3-fold after the booster dose (day 28). Although this group showed lower seroconversion than the others after a single dose, all groups had similar seroconversion of $\sim 1.3-1.4$-fold after the second dose (Fig.4).

To induce specific and effective antibody production against a pathogen, recombinant vaccine antigens need to preserve epitopes present in the native protein. The rSeM protein was able to induce specific IgG (Fig.5), which also recognized the native protein (SeM) in S. equi whole cells (Fig.4). These were produced after a single dose $(20 \mu \mathrm{g})$, confirming that the construct maintained important epitopes of the native protein

Vaccinated mice developed a 0.9 -fold seroconversion level against the rSeM antigen on day 14, and up to 1.8 -fold after the booster dose on day 28 (Fig.5). Moreover, the seroconversion against $S$. equi whole cells was of 1.2 -fold and 2.3 -fold, on days 14 and 28, respectively (Fig.4). The difference observed between the two antigens may be due to the amount of each antigen that adhered on the plate. However, this was out of the study scope. Mice vaccinated with the combination vaccine composed of $S$. equi inactivated cells and $\mathrm{rSeM}$ protein, showed a 1.3 -fold seroconversion to the total antigen (S. equi) after a single dose. This level was maintained until the end of the study (Fig.4). The antibody response to $\mathrm{rSeM}$ was 0.9 -fold on day 14, and 2.4-fold on day 28 (Fig.5). The level of anti-S. equi and anti-rSeM antibodies induced in this vaccine group was higher than in the other groups (bacterin and rSeM). This was expected due the presence of both antigens, total $S$. equi cells and recombinant SeM protein.

The nature of an immune response to a defined antigen is established by several factors such as the use of adjuvants, antigen concentration, the administration route and host genetics (Lima et al. 2004). We selected aluminum hydroxide to enhance the immune response because its use has been well documented (since 1932) and is notoriously safe. This adjuvant enables a slow release of the antigen (Spickler \& Roth 2003), prolonging its exposure to APCs and lymphocytes. Aluminum-based vaccines induce a predominantly Th2 response. This effect has been associated with the activation of the inflammatory cascade through NLRP3 and caspase-1 signaling (Kool et al. 2008).
Studies show that the presence of anti-SeM antibodies can be correlated with protective immunity against an $S$. equi infection (Mallicote 2015). The SeM protein allows $S$. equi adhesion onto host tissues. When antibodies bind to this protein they prevent or hinder the pathogen's entry into the cell (Harrington et al. 2002). In the present study, vaccinated mice developed antibodies specific to the native and recombinant SeM protein. Mice were challenged in order to ensure that the antibody response protected against lethal infection and determine vaccine efficacy. A lethal dose $50\left(\mathrm{LD}_{50}\right)$ experiment for $S$. equi subsp. equi was performed using three groups ( 5 mice/group) of Balb/c mice. Intraperitoneal inoculation of the mice with $10^{1}, 10^{2}$ or $10^{3} \mathrm{CFU}$ of $S$. equi was performed, and animals were observed for $96 \mathrm{~h}$. The assay evidenced that $10^{1}$ S. equi CFU were able to cause lethal infection in 50$70 \%$ of inoculated mice (Fig.6). Therefore, for the challenge/ protection assay we used a dose of $10^{2} S$. equi $\mathrm{CFU}$, equivalent to $10 \times \mathrm{LD}_{50^{\circ}}$. In the protection assay all experimental groups $(1,2,3$ and 4$)$ were challenged. Vaccinated mice, with any of the formulations evaluated, remained healthy after the challenge, while the Control Group, inoculated with PBS and $\mathrm{Al}\left(\mathrm{OH}_{3}\right)$, reached endpoint criteria $96 \mathrm{~h}$ after infection (Fig.7).

This result shows that a vaccine with $\mathrm{rSeM}$ protein can prevent $S$. equi infection when used in combination with the bacterin as well as separately. In our study anti-SeM antibodies were present in the serum of vaccinated animals. This is consistent with previous evidence that the presence of anti-SeM antibodies is related to protection against strangles (Harrington et al. 2002). Previous studies have demonstrated the ability of the rSeM protein to induce high levels of antirSeM IgG in mice and horses. This was achieved with different adjuvants, such as aluminum hydroxide and LTB, and even without adjuvants (Maciel et al. 2017). In this study, we report the protective response triggered by $\mathrm{rSeM}$. In a pilot assay, intramuscular immunization was evaluated in horses, which developed a rSeM specific immune response without adverse effects. Nevertheless, studies on the effectiveness and duration of the immunity against $S$. equi in horses are still ongoing.
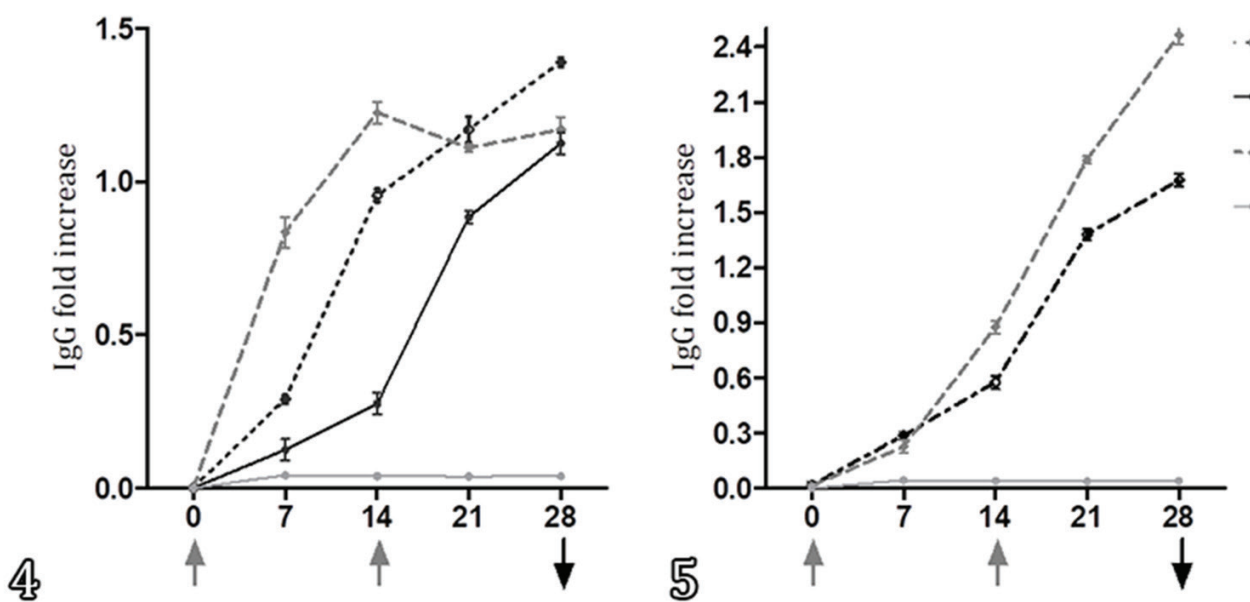

•. $\mathrm{rSeM}-\mathrm{Al}(\mathrm{OH})_{3}$ (group 1)

$\rightarrow$ S. equi $-\mathrm{Al}(\mathrm{OH})_{3}$ (group 2)

- S. equi - rSeM - $\mathrm{Al}(\mathrm{OH})_{3}$ (group 3)

$\therefore \mathrm{PBS}+\mathrm{Al}\left(\mathrm{OH}_{3}\right)$ (group 4)

$\uparrow$ Vaccination day
$\downarrow$ Challenge day

Fig.4-5. Humoral immune response. The data represent the means (+/- standard deviation) of the fold increase in the level of IgG against (4) Streptococcus equi subsp. equi cells and (5) anti-rSeM protein evaluated by indirect ELISA. 

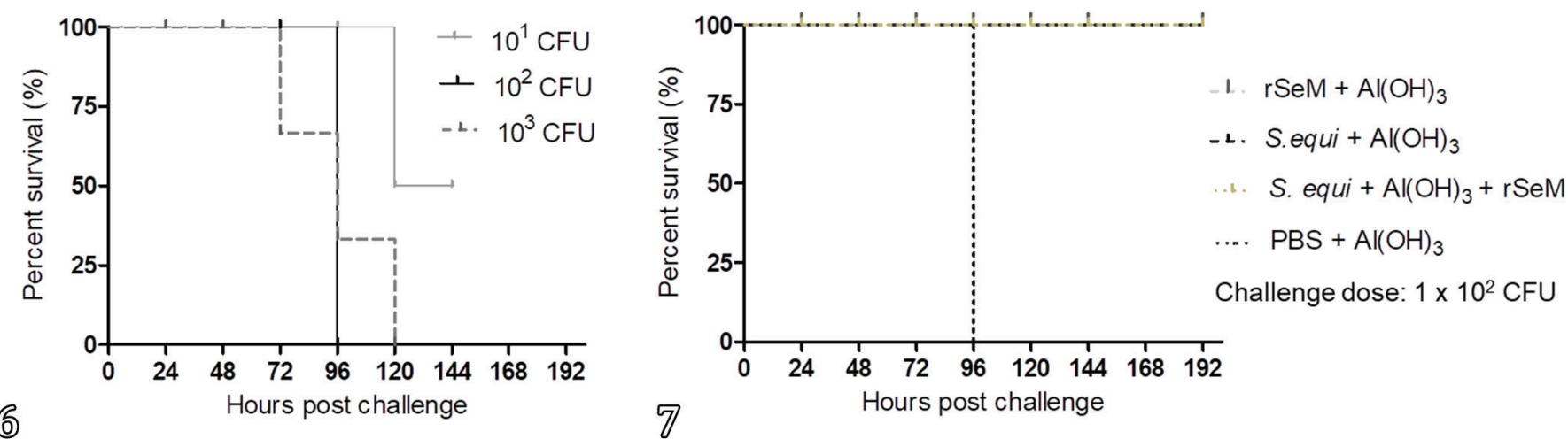

Fig.6-7. Survival challenge. (6) Determination of $\mathrm{LD}_{50}$ Mice were challenge with $10^{1}, 10^{2}$ or $10^{3} \mathrm{UFC}$ of Streptococcus equi subsp. equi (5 per group). (7) Protection against lethal challenge. Survival of mice vaccinated with S. equi, rSeM protein, S. equi-rSeM or PBS (Control Group) challenged with a lethal dose of $S$. equi subsp. equi, containing $10^{2} \mathrm{CFU}$, equivalent to $10 \times \mathrm{LD}_{50}$.

\section{CONCLUSION}

Together, our results suggest that the rSeM can be used in the development of vaccines against Strangles, associated or not with the whole inactivated bacteria. Due to its immunogenicity and its capability to stimulate antibodies, as well as crossprotective immunity. Thus, rSeM association with a bacterin is a promising alternative to improve vaccines against Strangles.

Author contribuitions.- Rosa M.C. and Conrad N.L. contributed equally to this work.

Acknowledgements.- We also thank to "Coordenação de Aperfeiçoamento de Pessoal de Nível Superior" (CAPES), Brazil - Finance Code 001 and "Conselho Nacional de Desenvolvimento Científico e Tecnológico" (CNPq) for scholarships.

Conflict of interest statement.- The authors declare no conflict of interest.

\section{REFERENCES}

Acke E., Midwinter A.C., Lawrence K., Gordon S.J.G., Moore S., Rasiah I., Steward K., French N. \& Waller A. 2015. Prevalence of Streptococcus dysgalactiae subsp. equisimilis and S. equi subsp. zooepidemicus in a sample of healthy dogs, cats and horses. N. Z. Vet. J. 63(5):265-271. <https://dx.doi.org/10 $.1080 / 00480169.2015 .1016133><$ PMid:25695401>

Araujo I.L., Dummer L.A., Rodrigues P.R.C., Santos Jr A.G., Fischer G., Cunha R.C. \& Leite F.P.L. 2018. Immune responses in bovines to recombinant glycoprotein $\mathrm{D}$ of bovine herpesvirus type 5 as vaccine antigen. Vaccine 36(50):7708-7714.<https://dx.doi.org/10.1016/j.vaccine.2018.10.080> $<$ PMid:30381153>

Boyle A.G., Timoney J.F., Newton J.R., Hines M.T., Waller A.S. \& Buchanan B.R. 2018. Streptococcus equi infections in horses: guidelines for treatment, control, and prevention of strangles - revised consensus statement. J. Vet. Intern. Med. 32(2):633-647. <https://dx.doi.org/10.1111/jvim.15043> <PMid:29424487>

Flock M., Jacobsson K., Frykberg L., Hirst T.R., Franklin A., Guss B. \& Flock J.-I. 2004. Recombinant Streptococcus equi proteins protect mice in challenge experiments and induce immune response in horses. Infect. Immun. 72(6):3228-3236. <https://dx.doi.org/10.1128/IAI.72.6.32283236.2004><PMid:15155624>

Hamlen H.J., Timoney J.F. \& Bell R.J. 1994. Epidemiologic and immunologic characteristics of Streptococcus equi infection in foals. J. Am. Vet. Med. Assoc. 204(5):768-775. <PMid:8175473>
Harrington D.J., Sutcliffe I.C. \& Chanter N. 2002 The molecular basis of Streptococcus equi infection and disease. Microbes Infect. 4(4):501-510. <https://dx.doi.org/10.1016/s1286-4579(02)01565-4><PMid:11932201>

Kool M., Soullié T., Van Nimwegen M., Willat M., Muskens F., Jung S., Hoogsteden H., Hammad H. \& Lambrecht B. 2008. Alum adjuvant boosts adaptive immunity by inducing uric acid and activating inflammatory dendritic cells. J. Exp. Med. 205(4):869-882. <https://dx.doi.org/10.1084/jem.20071087>

Libardoni F., Machado G., Gressler L.T., Kowalski A.P., Diehl G.N., Santos L.C., Corbellini L.G. \& Vargas A.C. 2016. Prevalence of Streptococcus equi subsp. equi in horses and associated risk factors in the State of Rio Grande do Sul, Brazil. Res. Vet. Sci. 104:53-57. <https://dx.doi.org/10.1016/j. rvsc.2015.11.009><PMid:26850537>

Lima K.M., Santos S.A., Rodrigues Jr J.M. \& Silva C.L. 2004. Vaccine adjuvant: it makes the difference. Vaccine 22(19):2374-2379. <https://dx.doi. org/10.1016/j.vaccine.2003.12.030 > <Mid:15193397>

Lindahl S., Söderlund R., Frosth S., Pringle J., Båverud V. \& Aspán A. 2011. Tracing outbreaks of Streptococcus equi infection (strangles) in horses using sequence variation in the seM gene and pulsed-field gel electrophoresis. Vet. Microbiol. 153(1/2):144-149. <https://dx.doi.org/10.1016/j. vetmic.2011.03.027><PMid:21511406>

Maciel F., Magalhães C.G., Moraes C.M., Rosa M.C., Mendonça M., Moreira A.N., Dummer L.A., Finger P.F., Ferreira M.R.A., Leite F.P.L. \& Conceição F.R. 2017. Imunogenicidade da proteína M recombinante de Streptococcus equi subsp. equi coadministrada com um adjuvante molecular. Arq. Bras. Med. Vet. Zootec. 69(5):1351-1356. <https://dx.doi.org/10.1590/1678-4162-9288>

Mallicote M. 2015. Update on Streptococcus equi subsp. equi infections. Vet. Clin. N. Am., Equine Pract. 31(1):27-41. <https://dx.doi.org/10.1016/j. cveq.2014.11.003><PMid:25600455>

Moraes C.M., Conceição F.R., Rocha A.S.R., Santos Júnior A.G., Ribas L.M., Vargas A.P.C., Nogueira C.E.W., Gil-Turnes C. \& Leite F.P.L. 2014. Cloning, expression and characterization of SeM protein of Streptococcus equi subsp. equi and evaluation of its use as antigen in an indirect ELISA. Arq. Bras. Med. Vet. Zootec. 66(4):1015-1022. <https://dx.doi.org/10.1590/1678-6034>

Moraes C.M., Silva M.S., Vargas A.P.C, Nogueira C.E.W., Leite F.P.L. \& Gil-Turnes C. 2009. Immunogenicity and cross reactivity indices of Streptococcus equi subsp. equi strains isolated from cases of Strangles and commercial vaccines. Ciência Rural 39(5):1459-1464. <https://dx.doi.org/10.1590/ s0103-84782009005000092>

Pace J.L., Rossi H.A., Esposito V.M., Frey S.M., Tucker K.D. \& Walker R.I. 1998. Inactivated whole-cell bacterial vaccines: current status and novel strategies. Vaccine 16(16):1563-1574. <https://dx.doi.org/10.1016/ S0264-410X(98)00046-2><PMid:9711805>

Ramos C.R.R., Abreu P.A.E., Nascimento A.L.T.O. \& Ho P.L. 2004. A high-copy T7 Escherichia coli expression vector for the production of recombinant 
proteins with a minimal N-terminal His-tagged fusion peptide. Braz. J. Med. Biol. Res. 37(8):1103-1109. <https://dx.doi.org/10.1590/S0100879X2004000800001>

Robinson C., Frykberg L., Flock M., Guss B., Waller A.S. \& Flock J.-I. 2018. Strangvac: a recombinant fusion protein vaccine that protects against strangles, caused by Streptococcus equi. Vaccine 36(11):1484-1490. <https://dx.doi.org/10.1016/j.vaccine.2018.01.030><PMid:29398274>

Spickler A.R. \& Roth J.A. 2003. Adjuvants in veterinary vaccines: modes of action and adverse effects. J. Vet. Intern. Med. 17(3):273-281. <https:// dx.doi.org/10.1111/j.1939-1676.2003.tb02448.x><PMid:12774966>

Strugnell R., Zepp F., Cunningham A. \& Tantawichien T. 2011. Vaccine antigens. Perspect. Vaccinol. 1(1):61-88. <https://dx.doi.org/10.1016/j. pervac.2011.05.003>

Sturbelle R.T., Conceição R.C.S., Da Rosa M.C., Roos T.B., Dummer L. \& Leite F.P.L. 2013. The use of quorum sensing to improve vaccine immune response. Vaccine 32(1):90-95.<https://dx.doi.org/10.1016/j.vaccine.2013.10.065> $<$ PMid:24188753>
Timoney J.F. \& Eggers D. 1985. Serum bactericidal responses to Streptococcus equi of horses following infection or vaccination. Equine Vet. J.17(4):306-310. <https://dx.doi.org/10.1111/j.2042-3306.1985.tb02505.x><PMid:4076146>

Timoney J.F., Artiushin S.C. \& Boschwitz J.S. 1997. Comparison of the sequences and functions of Streptococcus equi M-like proteins SeM and SzPSe. Infect. Immun. 65(9):3600-3605. <https://dx.doi.org/10.1128/iai.65.9.36003605.1997><PMid:9284125>

Walker P.D. 1992. Bacterial vaccines: old and new, veterinary and medical. Vaccine 10(14):977-990. <https://dx.doi.org/10.1016/0264-410x(92)90106-t> <PMid:1471428>

Waller A.S., Paillot R. \& Timoney J.F. 2011. Streptococcus equi: a pathogen restricted to one host. J. Med. Microbiol. 60(Pt 9):1231-1240. <https:// dx.doi.org/10.1099/jmm.0.028233-0 ><PMid:21757503>

Wyngaarden J.B. \& Smith L.H. 1985. Cecil Tratado de Medicina Interna. Vol.1 e 2. Guanabara Koogan, Rio de Janeiro. 2926p.

Zhang W. 2014. Progress and challenges in vaccine development against Enterotoxigenic Escherichia coli (ETEC)-associated porcine post- weaning diarrhoea (PWD). J. Vet. Med. Res. 1(2):1006. 